\title{
«Волшебный сон Востока»: гендерная и национальная проблематика в травелогах Елены Димитриевич
}

\author{
А. Г. БОДРОВА \\ Кафедра славянской филологии, Санкт-Петербургский государственный университет, \\ Университетская наб., д. 11, RU-199034 Санкт-Петербург \\ E-mail: bodrann@gmail.com
}

(Received: 14 November 2016; accepted: 3 February 2017)

\begin{abstract}
The paper deals with the national and gender specificity of Jelena Dimitrijević's travelogues. This specificity is significantly caused both by the phenomenon of women travelling, its literary representation (the female author achieves a special status leaving her home as the place prescribed by the patriarchal culture to women) and her own Balkan culture identity. Dimitrijević's texts are analyzed here in connection with the concept of the Balkan orientalism and the theory of nomadic subject. The paper considers the explicitly transnational character of Dimitrijević's writings.
\end{abstract}

Keywords: Jelena Dimitrijević, travelogue, gender, nation, women's travel, nomadism, Balkan orientalism

В последнее время к произведениям сербской писательницы Елены Димитриевич (Јелена Димитријевић, 1862-1945) все чаще обращаются литературоведы (СлАПшАК 1998, Косн 2005 и др.). В Сербии в городе Ниш в 2004 году проходила конференция, посвященная ее жизни и творчеству. Очевидно стремление исследователей по-новому взглянуть на фигуру Димитриевич, а также привлечь внимание к дальнейшему изучению произведений писательницы.

В России ее творчество остается малоизвестным, хотя примечателен тот факт, что ее роман «Нове» (1912) был переведен на русский язык Б. И. Ярхо и в 1928 г. опубликован под названием «Новые женщины» (ДимитриЕвич 1928).

По словам исследовательницы Аны Стьеля, в биографии Димитриевич есть «темные» места, иногда биографические источники содержат противоречивую информацию (СТЈљљА 2012). ${ }^{1}$ Известно, что писательница и поэтесса Елена Димитриевич родилась в многодетной, но очень состоятельной семье в городе Крушевац в княжестве Сербия. С детства Елена проявляла страсть к чтению книг, но из-за того, что в возрасте 11 лет она повредила глаз, ей

\footnotetext{
${ }^{1}$ Биографию и краткий обзор творчества Димитриевич см. в работе А. Стьеля и на портале, посвященном теории и истории женской литературы на сербском языке до 1915 года: http://knjizenstvo.etf.bg.ac.rs/sr/authors/jelena-dimitrijevic.
} 
пришлось отказаться от идеи продолжить образование в Высшей женской школе в Белграде. Врачи не рекомендовали ей напрягать зрение, и не советовали читать и писать, чтобы совсем не ослепнуть, поэтому Димитриевич приходилось это делать тайно. После того как будущая писательница в 19 лет вышла замуж за военного, ее жизнь изменилась - муж с одобрением относился к увлечению Елены книгами, они много путешествовали. 17 лет супруги прожили в городе Ниш (южная Сербия), а потом переехали в Белград, где Елена, за исключением времени, проведенного в путешествиях, оставалась до конца жизни.

Елена Димитриевич в годы балканских войн работала санитаркой в белградском госпитале (1912-1913). Первая мировая война принесла писательнице тяжелое испытание - в 1915 г. погиб ее супруг.

В литературу Димитриевич вошла как поэтесса. Критика ее сравнивала с Сафо, азербайджанским поэтом Мирзой Шафи Вазехом и чаще всего с сербом Йованом Иличем из-за увлечения темой «Востока» (Пековић 1986: 3).

Елена Димитриевич, по сравнению с современницами, много путешествовала, о некоторых поездках она написала путевые заметки. Травелоги занимают значительное место в ее творчестве: «Письма из Салоник» (Писма из Солуна, 1918), «Письма из Индии» (Писма из Индије, 1928), «Семь морей и три океана» (Седам мора и три океана, 1940), «Новый свет или год в Америке» (Нови свет или у Америци годину дана, 1934) и др.

Еще в молодости, живя в южной Сербии (г. Ниш), она увлеклась «Востоком», познакомилась с жизнью турецких гаремов (в 1897 г. было опубликовано произведение «Письма из Ниша о гаремах»). Тема «Востока» будет фигурировать не только в поэзии Димитриевич, но и в прозаических текстах (в романе «Новые женщины», в многочисленных травелогах).

Материалом данного исследования стали травелоги «Письма из Салоник», «Письма из Индии» и «Семь морей и три океана», в которых автор обращается к так называемым восточным странам. Елена Димитриевич побывала в Османской империи (Салоники на момент посещения города сербской писательницей входили в состав этого государственного объединения), Египте (Александрия, Каир, Луксор), Палестине (Иерусалим, Вифлеем), Сирии (Дамаск), Ливане (Бейрут), Индии (Бомбей - ныне Мумбаи), Бенаресе (Варанаси), Калькутте и Мадрасе (Ченнаи).

Общим местом в исследованиях, затрагивающих тему «Востока», является привлечение понятия ориентализма (САид 2006), подразумевающего под «Востоком» конструкт, созданный учеными и литераторами Европы. В статье рассматривается специфика ориентализма в травелогах писательницы, происходящей из балканского пространства, во многом пограничного т. е. в понимании автора не совсем восточного и не совсем западного. «Я Балканы отделяю от Востока, потому что они немного Восток, а немного Запад» (Димитријевић 1940: 44). В западной культуре распространена оппозиция «Восток-Запад», восходящая к дихотомии «я» и «другой / чужой»: Востокженственный, пассивный, подчиненный, отсталый, Запад - маскулинный, 
прогрессивный, доминантный. В этой связи интересно рассмотреть соотношение «восточной» и «женской» темы в путевых заметках Димитриевич, а также их взаимосвязь с национальными конструктами. ${ }^{2}$

Писательница на протяжении всей жизни интересовалась женским вопросом, принимала активное участие в работе сербских женских организаций. Женская тема, бесспорно, является главной темой творчества Димитриевич. По концепции Симоны де Бовуар, женщина в обществе - это «другой» (БовУАР 1997: 28). Поэтому женские травелоги можно определить как взгляд «другого» на «другого/чужого». Женщина, отправившаяся в путешествие, уже самим этим фактом приобретает в культуре особый статус. Она, покинув дом - традиционно отводимое женщине место (HABINGER 2006: 43), сферу приватного, нарушает границы принятого порядка. Ее начинание имеет, бесспорно, освобождающую функцию, которая во многом отличает мужское путешествие от женского. Конечно, невозможно отрицать общую для любого путешествия интенцию получения свободы или бегства, стремления к пересечению границ, однако в случае женского путешествия речь идет о дополнительной смысловой нагрузке данного феномена - происходит переход в более нестабильное положение (из дома в чужую страну).

Путешествие женщины пожилого возраста, занимающей маргинальное положение в обществе, могло вызывать еще больше осуждения. К теме «старой» женщины, а также к культурному феномену старой девы уже не раз обращались исследователи (см. BAUMGARTEN 1997). ${ }^{3}$ Например, Индию Елена Димитриевич посетила в возрасте 65 лет. Для Сербии того времени этот поступок был в высшей степени необычным. В травелоге «Семь морей и три океана» она пишет об осуждении, которое вызвало ее намерение отправиться в путешествие: «Многие из наших соотечественников..., услышав, что я собираюсь в путь, в Египет, спросили бы меня с удивлением: „Откуда такой кураж у нашей женщины, женщины ваших лет («женщины ваших лет» непременно было бы сказано) отправиться в такой дальний путь, да еще и одной?“” (Димитријевић 1940: 12).

Димитриевич комментирует данное высказывание и связывает его с отношением к пожилым женщинам на Балканах: «,Женщина ваших лет!“ Да, так многие скажут. Потому что на Балканах живут неспешно; умирают, как везде, а стареют быстро. Многие и сами себя записывают в старики, когда им только за пятьдесят, а некоторые еще и раньше...: чтобы оправдать свою бездеятельность» (Димитријевић 1940: 14).

\footnotetext{
2 Постнеклассический (или деконструктивистский) подход к нации представляется наиболее продуктивным: нация рассматривается как плод коллективного воображения, «воображаемое сообщество» (АндеРСОН 2001: 30), как продукт дискурсивных практик.

${ }^{3}$ Примечательно, что соотечественница Димитриевич, известная писательница Исидора Секулич (1877-1958) поднимает тему старых дев в травелоге «Письма из Норвегии» (1914). Она рассказывает, что в Сербии старые девы совершенно бесправные существа, в отличие от норвежек, имеющих в социуме высокий статус.
} 
Писательница-путешественница так полемизирует на тему старости: «О, люди! Не повторяйте „женщина ваших лет!“, ведь есть молодые старики и старая молодежь. И не забывайте и в своей стране чужую пословицу: „Мне столько лет, насколько я себя чувствую“. И наконец, вспомните, что дух человека не имеет возраста» (Димитријевић 1940: 14).

Пример из травелога Димитриевич свидетельствует об особом статусе Балкан и балканской женщины - путешествия западноевропейских женщин, по словам Димитриевич, в XX веке не вызывали ни у кого удивления или осуждения: «И никто, никто, ни англичане, ни американцы, меня не спрашивает: „Откуда у меня кураж“, и почему я путешествую» (Димитријевић 1940: 15).

Димитриевич утверждает, что статус женского путешествия без сопровождения тоже изменился: «Прошли времена, когда женщины не путешествовали одни» (ДимитРијевић 1940: 15).

Сербская писательница в травелогах уделяет детальное внимание так называемым «женским темам» - дому, одежде, быту. Например, она сравнивает дома турецкие и сирийские (в турецких домах два двора, а в сирийских три), и рассказывает о правилах в гаремах: женщине нельзя показываться мужчинам, исключение составляют родственники мужского пола.

Травелоги сербской писательницы содержат антропологические описания местных жительниц. Она подробно останавливается в своем повествовании на внешнем облике, деталях одежды. Иногда с иронией сравнивает украшения на восточных женщинах с побрякушками на верблюдах, которых она видит в пустыне. Очень яркий макияж у египтянок вызывает у нее ассоциации с египетскими мумиями. В самом раннем травелоге «Письма из Салоник» Димитриевич признается, что ее потрясла почерпнутая из газеты информация о Младотурецкой революции 1908 г. В заметке было написано, что турчанки с непокрытыми головами вышли на улицы. Сербскую писательницу это настолько взволновало, что она поменяла планы: «Хотела ехать в Европу, но передумала [...] более сильная любовь к Востоку победила» (Димитријевић 1918: 6). Получается, что желание узнать, на самом ли деле турчанки изменили традиции прятать лицо, заставило Димитриевич отправиться в путь. Большая часть данного травелога посвящена женскому вопросу в Турции. Покрывало на голове женщины, как и ее украшения, становятся в текстах Димитриевич символом порабощенности. Доминирование черного цвета в одежде египтянок также трактуется писательницей в «Семи морях и трех океанах» как признак несвободы. Например, она отмечает, что в Каире местные жители мужского пола носят одежду всевозможных ярких цветов, а женщины одеты в черное (Димитријевић 1940: 207).

Сербская писательница заявляет, что одежда на Востоке очень важна: «Поскольку я готовилась к путешествию по Востоку, а мне было известно, что значит одежда на Востоке, я обеспечила себя в Париже туалетами по последней парижской моде» (Димитријевић 1940: 373). Примечательно, что эту фразу Димитриевич пишет, когда наряжается на встречу с Али-Пашиницей, 
представительницей женского движения в Дамаске, которая принимает путешественницу в своем дворце Харун-аль-Рашид. Димитриевич знакомится с ее дочерьми, которые свободно говорят по-французски, а с Али-Пашиницей она общается по-турецки. Во время визита Димитриевич не только осматривает дворец в восточном стиле (в тексте содержится его подробнейшее описание), но и обсуждает с хозяйкой тему женской эмансипации. Али-Пашиница сравнивает ситуацию в Турции и Египте: «В Турции женский вопрос уже решен, а решали его и решили просвещенные турецкие женщины коллективно, и принесли решение Мустафе Кемалю на подпись. В то время как в Египте говорят только об одной женщине [здесь речь идет о председательнице Союза египетских феминисток по имени Хода Шаарауи - А. Б.] она сама начала движение, сама решает и, возможно, решит; но подпишет ли Фуад Первый - это вопрос» (Димитријевић 1940: 378). Димитриевич вносит в повествование восточный колорит, рассказывая историю дворца, который построил один из предков Али-Паши для своей любимой жены, бывшей рабыни Зенаиды из Грузии. Димитриевич комментирует, что таких историй она наслушалась в больших количествах по турецким гаремам. Однако ее история претендует на подлинность - ей удается познакомиться с Зенаидой. Этой женщине, по словам ее родственников, 128 лет.

Димитриевич не раз в своих текстах пишет о «волшебном сне Востока», в котором есть прелесть (с большой любовью она описывает восточный колорит), но который также становится символом несвободы, непросвещенности. Елена Димитриевич предлагает читателю стереотипы о жизни женщин Востока, а затем их разрушает. Например, она не раз подчеркивает образованность восточных женщин в гаремах - они прекрасно владеют несколькими языками, в том числе европейскими, много читают. В травелоге «Письма из Салоник» турчанки комментируют роман Пьера Лоти «Азиаде», действие которого развивается в основном в Стамбуле, о любви турчанки и европейца, и утверждают, что там ничего реального не описывается (Димитријевић 1918: 33). Можно сказать, что угнетенным женщинам Димитриевич дает право голоса, возможность высказать свое мнение по поводу западноевропейских восточных сексуальных фантазмов.

Рассказывая о своих спутницах, англичанках, француженках, американках, сербская писательница подчеркивает, что многие из них не владеют иностранными языками, плохо знают историю и географию, но много путешествуют, в отличие от запертых в гаремах жительниц Востока. Так одна американка в травелоге «Семь морей и три океана» на вопрос Димитриевич, на каком языке она будет говорить во время кругосветного путешествия, ответила: «Боже мой, на английском. На каком еще, если другого я не знаю!.. Путешественники из Европы и Америки чувствуют себя с английским языком как дома, даже на Дальнем Востоке. И на заброшенных островах вы услышите английский язык!» (Димитријевић 1940: 15). В этом же травелоге Димитриевич разбивает стереотип о том, что «сладкоречивость», привычка говорить образами свойственны лишь восточным женщинам (хотя ранее об этой черте 
повествовательница неоднократно упоминала в текстах). Ее спутница, американка, при расставании с Димитриевич была сентиментальна, заплакала и сказала: «Я теперь птица с раненым крылом!» (Димитријевић 1940: 349).

Сербская писательница предлагает альтернативное феминистское прочтение истории, ее особенно интересует роль женщин. Например, говоря о прошлом Египта, Димитриевич размышляет о Клеопатре, о созданном вокруг ее фигуры мифе. Однако современность также вызывает интерес автора. Ее травелоги имеют ценность и как документальное свидетельство - со всеми «историческими» личностями Димитриевич встречается лично.

В Египте самым значимым для писательницы событием становится знакомство, а затем общение с известной феминисткой, политиком Ходой Шаарауи. Примечательно, что, давая характеристику своей новой знакомой, Димитриевич пишет, что Шаарауи в первую очередь патриотка, а затем феминистка (Димитријевић 1940: 210). В этом случае очевидна связь национальной и гендерной проблематики в травелогах Димитриевич, которая в своих текстах зафиксировала процессы как национального возрождения (в Египте, Индии, Сербии, Османской Империи), так и женской эмансипации в первой половине XX в. О тесной связи нации и гендера свидетельствуют названия журналов, начавших появляться с конца XIX в. Хода Шаарауи, по рассказам Димитриевич, основала газету «Эжиптьенн» (Египтянка), в Сербии известным женским изданием было «Српкиня» (Сербка).

Специфику травелога определяет позиция путешественника. Национальная и гендерная идентичность самой Димитриевич отразилась на восприятии другой страны. Она путешествует именно как представительница сербской нации. В Индии Димитриевич знакомится с Тагором (встрече с индийским поэтом посвящена большая часть травелога «Письма из Индии»). Эту страну сербская писательница связывает с фигурами Ганди и Тагора - борцами за свободу нации. Так, она сопоставляет индийский и сербский народ, проводит параллель борьбы Индии за независимость с освобождением родной Сербии. К примеру, она именно своим происхождением объясняет тот факт, что ее приняли в доме Р. Тагора: «Потому что большой Индии импонирует маленькая Сербия; и ее берут как образец для осуществления своих идеалов» (Димитријевић 1928: 12). В данной ситуации имеется в виду борьба за национальную независимость.

Женская тема, проблемы национальной и гендерной идентичности, их соотношение отличает травелоги Димитриевич от описаний Востока у других авторов. Наиболее ярко эту взаимосвязь гендерной и национальной идентичности демонстрирует высказывание Е. Димитриевич из травелога «Семь морей и три океана»: «Мы, женщины сербские, не меньшие патриотки, чем женщины египетские... Не принадлежит ли большая часть заслуги, что из маленькой Сербии возникла большая Югославия, сербским женщинам?» (Димитријевић 1940: 213).

Следует обратить внимание на то, что Димитриевич осознает, что женская эмансипация - процесс сложный. Так, она считает хорошим знаком, что 
мужчины стали писать на женскую тему (Димитријевић 1918: 59). При этом, по мнению писательницы, довольно сложно поменять многовековые устои. Женщинам Востока, которых, по словам одного персонажа, младотурчанки, «эгоизм их мужей» запер дома (Димитријевић 1918: 47), недостаточно просто раскрыть лица - они должны измениться сами и добиться признания в социуме, а до таких перемен еще далеко. В данном контексте показательна сцена в парке из травелога о Салониках. Повествовательница вспоминает, как в честь государственного праздника в парке собрались мужчины, а женщины стояли за оградой, не смея зайти внутрь.

Димитриевич считает, что женщинам важно измениться внутренне, а не только переодеться в европейское платье (данная тема фигурирует и в романе «Новые женщины»). Писательница констатирует, что эмансипация иногда имеет только поверхностный характер. Так, внешность женщин из Александрии и Назарета, одетых по-европейски (чулки, короткие юбки, даже высокие каблуки), но с покрытыми головами, вызывает насмешку Димитриевич. Она проводит параллель с ситуацией на Балканах, пространстве со смешанной идентичностью, которое нельзя отнести к Востоку или Западу. Повествовательница дважды рассказывает (христианке из Сараево) шутку о наряде боснийской женщины в день ее свадьбы в период оккупации мусульманской Боснии Австро-Венгрией. На ней было европейское платье, а на голове феска. Женщину спросили, почему она так одета, и та ответила: «Платье - это оккупация, а феска - султан-властелин» (Димитријевић 1940: 338). Димитриевич переносит эту комичную модель на египтянок, которые ответили бы, по ее предположению: «платье и туфли - англичане, а покрывало и кольца с деревцем в носу - Кедив-властелин» (Димитријевић 1940: 44). А женщины из Назарета, возможно, по мнению Димитриевич, ответили бы: «короткая юбка и шелковые чулки - мандат, а покрывало на волосах - ибн Сауд-властелин» (Димитријевић 1940: 338).

При всем сочувствии и интересу к восточным женщинам Димитриевич не забывает о своей европейской идентичности - она путешествует как представительница христианской веры (в Иерусалиме), более того, как православная. В одном месте текста она заявляет, что возникшее в Азии христианство это религия самых культурных народов (Димитријевић 1940: 247). Возможно, данное отношение к христианству связано с положением женщин в исламе. Примечательно и то, что при посещении храма Гроба Господня она, увидев могилу Адама, задает своему проводнику провокационный вопрос - где находится могила Евы. В этом вопросе, как и в других эпизодах, в которых внимание писательницы обращено к роли женщины в истории или культуре (в Каирском музее она ищет изображения Клеопатры, неоднократно вспоминает о таланте легендарной Шахерезады), содержится стремление расшатать устоявшийся западноевропейский патриарахтный символический порядок, в котором женщине уготовано подчиненное положение.

Текст путешествия в Палестину пронизан библейскими реминисценциями. Помимо прямых цитат из Библии, в травелоге встречаются семейные 
воспоминания Димитриевич: о паломничестве одной ее родственницы в Иерусалим, о том, как будущая сербская писательница читала своей маме Библию вслух. В травелогах впечатления от увиденного Димитриевич связывает с личным опытом, со своей биографией. Она вспоминает и о своем детстве, и о смерти мужа. Общаясь в салоне с Ходой Шаарауи, Елена воскрешает в памяти, как сама принимала у себя по средам сербских студенток, с которыми сотрудничала в женском культурно-просветительском патриотическом обществе «Коло сербских сестер» (Коло српских сестрара). А, например, сравнивая Египет и Турцию, Е. Димитриевич вспоминает свою молодость, проведенную в общении с турчанками в гаремах, делится с читателем своими эмоциями: «Современный Египет мне напоминает Турцию в прошлом, ту Турцию, которую я знала еще в моей первой молодости, в которой я провела лучшие часы своей жизни, среди турецких женщин, я любила их, изучала их и писала о них, не только хорошо их узнав, но любя их и сочувствуя им». (Димитријевић 1940: 207). Данная тема эго-документа и его связи с феминисткой автобиографией требует отдельного исследования. Димитриевич создает не только путевые заметки с описаниями увиденного, но и предлагает вниманию читателя женский взгляд на историю, содержит автобиографические свидетельства. В ее случае наблюдается тесная связь жанра травелога с мемуарами и автобиографией.

К сожалению, Димитриевич долго оставалась за пределами канона сербской литературы. Убедительным представляется объяснение этого факта, предложенное исследовательницей Светланой Слапшак. По ее мнению, Восток является для Балкан прошлым, к которому не хочется возвращаться. Для Сербии Османская империя является поработителем, ставшим причиной культурного регресса. Этим и отличаются, по словам Слапшак, травелоги Димитриевич от западноевропейских женских путевых заметок. Сербская культура «принимает» турецкую тему только в форме закрытого ностальгического прошлого, безжизненного, полного фантазмов, «натуралистического мелодраматизма» (СлАПшАк 1998). Таковым примером, по Слапшак, является творчество сербского писателя Боры Станковича, воспевавшего юг Сербии. «Живое» свидетельство Димитриевич о жизни гаремов с героинями, которые хотят избавиться от прошлого, начать жить по-другому, не могло найти места в сербском каноне того времени. Слапшак называет Димитриевич, владевшую многими языками, лингвистической номадой и рассматривает ее творчество в русле феминисткого номадизма (БРАйдотти 2001). С номадическим субъектом соотносит в своей диссертации сербскую писательницу и исследовательница Елена Петрович. Действительно, в текстах Елены Димитриевич много иностранных вкраплений (на английском, французском), особое внимание обращают на себя турцизмы. Так, например, без словаря турцизмов чтение текста «Писем из гарема» становится проблематичным. В данном феномене можно увидеть осознанное намерение расшатывать дискурсивные системы. Как уже говорилось выше, героини Димитриевич говорят на разных языках. Сама Димитриевич нередко выступает в роли переводчицы 
(например, встретив на берегу Иордана русских паломниц, Елена переводит своим спутницам их разговор на английский язык).

«Номада-полиглот практикует эстетический стиль, основанный на сопереживании несовместимостей, повторений, произвольности тех языков, с которыми он(а) имеет дело. Письмо для полиглота есть процесс расформировывания иллюзорной стабильности фиксированных идентичностей, тычок иглой в пузырь онтологических безопасностей, выдуваемый освоением [лишь] одной лингвистической территории... Писать в таком модусе - значит расшатывать оседлость слов, дестабилизируя значения здравого смысла и деконструируя укоренившиеся формы сознания. [...] Письмо - процесс не только постоянного перевода, но и последовательная адаптация к различным культурным реалиям» (БРАйдотти 2001: 137-138). Данная характеристика прекрасно подходит как к творчеству сербской писательницы, представляющему собой межкультурный трансфер между «Востоком», «Западом» и Балканами, с постоянным подрыванием стереотипов и конструктов, так и к ее дискурсивной личности, которой свойственно стремление избегать укорененности, оседлости.

Продолжая дискуссию с соотечественниками в травелоге «Семь морей и три океана» о женском путешествии без сопровождения, Димитриевич пишет: «...как это я не боюсь умереть в пути. Но я уже сказала, что не боюсь смерти, ни на суше, ни на море. Какая разница, где будет моя могила, в Европе, Азии или Африке. Земля есть земля. Одно и то же тело разделили на пять частей и каждому дали имя - люди, не Бог. Я путешествую по нашей матери Земле, я не еду ни на Луну, ни на Марс. Какой смешной мне кажется ограниченность представлений! Ведь каждый верит в бессмертие души, а почему же не верят в то, что душа не знает пространства, как для нее не существует время... я не знаю... откуда душа пришла, куда уйдет. Что касается тела: оно подобно поношенному платью... Если душа его оставит среди мусульман - люди его замотают несколькими аршинами белого полотна и похоронят; если же оставит среди брахманов - они сожгут его на костре, а пепел бросят в Ганг...» (Димитријевић 1940: 16).

Елена Петрович справедливо замечает, что подобное ощущение является не результатом увлечением эзотерикой, а свидетельствует о критическом сознании, противящемся социально обусловленным ментальным и поведенческим моделям (РеTROVIĆ 2009: 308).

Таким образом, можно говорить о транснациональном, транскультурном характере травелогов Димитриевич, в которых очевиден как поиск, так и отказ от застывших идентичностей. Статус самой повествовательницы также оказывается неоднозначным: она путешествует как представительница Балкан, как сербская женщина, но вместе с тем как переводчица между культурами, между «Востоком» и «Западом», которая охотно переходит из одной системы ценностей в другую (она видит мир то глазами обитательниц гаремов, то как западноевропейская феминистка, то как сербская патриотка). При этом женская тема остается доминантной для всего ее творчества. 


\section{Литература}

АНДЕРСОН 2001 = АНДЕРСОН Б. Воображаемые сообщества. Размышления об истоках и распространении национализма. Москва, 2001.

БовУАР 1997 = БовУАР С. Второй пол. Т. 1-2. Москва, 1997.

БРАЙДОТТИ 2001 = БРАЙДОТтИ Р. Путем номадизма. В кн.: ЖЕРЕБКИН С. В. (ред.) Введение в гендерные исследования. Ч. 2. Хрестоматия. Харьков-Санкт-Петербург, 2001. 137-163.

Димитријевић 1918 = Димитријевић Ј. Писма из Солуна. Сарајево, 1918.

Димитријевић 1928 = Димитријевић Ј. Писма из Индије. Београд, 1928.

Димитријевић 1940 = ДимитРијевић Ј. Седам мора и три океана. Путем око света. Београд, 1940.

ДимитриЕВич 1928 = ДимитриЕвич Е. Новые женщиныл. Москва, 1928.

Пековић 1986 = Пековић С. Јеленина писма. In: Димитријевић Ј. Писма из Нииа о Харемима. Београд-Горњи Милановац, 1986. I-XV.

САид 2006 = САид Э. В. Ориентализм: западные концепџии Востока. Санкт-Петербург, 2006.

СлАПШАК 1998 = СлАПшАК С. Хареми, номади: Јелена Димитријевић. ПроФемина 15-16 (1998): 137-149. https://aleksandrazikic.wordpress.com/2014/10/02/2-10-2014.

СТЈЕљА 2012 = СтЈЕљА А. Јелена Ј. Димитријевић - трагом прве признате српске књижевнице. Кьижевна историја 147. Београд, 2012. 341-354.

BAUMgARTEN 1997 = BAUMgARTEN K. Hagestolz und alte Jungfer. Entwicklung, Instrumentalisierung und Fortleben von Klischees und Stereotypen über Unverheiratetgebliebene. Münster-New York-München-Berlin, 1997.

Habinger 2006 = Habinger G. Frauen Reisen in die Fremde. Diskurse und Repräsentationen von reisenden Europäerinnen im 19. und beginnenden 20. Jahrhundert. Wien, 2006.

Косн 2005 = Косн М. Гендер дискурс у акцији. Наратолошке трансгресије код списатељица на почетку двадесетог века. Случај: Јелена Димитријевић. In: Научни састанак слависта у Вукове дане 34/2. Београд, 2005. 255-268.

Petrović 2009 = Petrović J. Rod $i$ žensko autorstvo u književnoj kulturi i javnim diskursima u Jugoslaviji između dva svetska rata. Doktorska disertacija. Ljubljana, 2009.

Todorova 1997 = Todorova M. Imagining Balkans. Oxford University Press, 1997. 